\title{
Problemy emocjonalno-społeczne i behawioralne u dzieci $z$ centralnymi zaburzeniami przetwarzania słuchowego (CAPD) w ocenie rodziców
}

\section{Socio-emotional and behavioral problems in children with Central Auditory Processing Disorders (CAPD) as reported by their parents}

\author{
Joanna Rostkowska ${ }^{1}$, Joanna Kobosko², Katarzyna Lidia Kłonica² \\ 1 „Audioland”, Centrum Zdrowia Dziecka, Warszawa \\ ${ }^{2}$ Instytut Fizjologii i Patologii Słuchu, Światowe Centrum Słuchu, Kajetany
}

Adres autora: Joanna Rostkowska, „Audioland”, Centrum Zdrowia Dziecka, Al. Dzieci Polskich 20, 04-730 Warszawa, e-mail: j.rostkowska@czd.pl

\section{Streszczenie}

Wstęp: Obserwuje się wciąż wzrastającą liczbę dzieci zgłaszających problemy związane z komunikowaniem się. Są to pacjenci, u których przy prawidłowym słuchu obwodowym wychodzą nieprawidłowe wyniki testów psychoakustycznych wyższych funkcji słuchowych oraz potencjałów poznawczych typu P300, świadczące o problemach przetwarzania słuchowego na poziomie centralnym. Takie problemy skutkują często niepowodzeniami szkolnymi, a co za tym idzie - trudnościami o charakterze emocjonalno-społecznym i związanymi z komunikowaniem się.

Metoda: Badaniami objęto grupę 74 pacjentów ze zdiagnozowanymi zaburzeniami przetwarzania słuchowego. Grupę kontrolną stanowiło 75 dzieci ze szkół warszawskich. Do badań zastosowano Kwestionariusz Mocnych Stron i Trudności (SDQ) oraz Ankietę - oba narzędzia wypełniane przez rodziców.

Wyniki: Okazało się, że dzieci z CAPD manifestują znacząco więcej problemów ze zdrowiem psychicznym ogółem, tj. występują one 3,8 razy częściej niż w grupie dzieci o prawidłowym rozwoju z populacji ogólnej. Dzieci z CAPD przejawiają więcej problemów w sferze emocjonalnej, nadaktywności, koncentracji uwagi i kontaktów $\mathrm{z}$ rówieśnikami w porównaniu $\mathrm{z}$ dziećmi o typowym rozwoju.

Wnioski: Wyniki badań wskazują na konieczność włączenia w proces terapeutyczny grupowej lub indywidualnej terapii psychologicznej i treningu umiejętności komunikacyjnych.

Słowa kluczowe: zdrowie psychiczne • kwestionariusz SDQ • centralne zaburzenia przetwarzania słuchowego (CAPD)

Abstract

Introduction: We can observe an increasing number of patients reporting problems connected with broadly defined communication. Among patients with an accurate peripheral hearing, we can notice abnormal results of psychoacoustic tests of higher hearing functions and P300 cognitive potentials, showing problems with central auditory processing on the central level. This kind of difficulties frequently results in education failures and consequently in emotional, social and communication problems.

Method: The study included a group of 74 patients diagnosed with CAPD. The control group consisted of 75 children from Warsaw school. The study of this group of patients used the Strengths and Difficulties Questionnaire (SDQ) and survey (both of them were filled in by the parents).

Results: It turned out that children with CAPD manifest remarkably more problems with overall mental health, including significantly more emotional problems, problems with hyperactivity and inattention, as well as with peer relationship, in comparison to children without CAPD. The results of those difficulties is more detailed characterization of the group, with will allow a more effective therapy, better selection of specific methods, and a further prognosis of the results. 
Conclusions: The study results indicate the necessity of incorporating a group or individual psychological therapy and a specially designed communication skills training program into the therapy process.

Key words: mental health $•$ SDQ questionnaire $•$ Central Auditory Processing Disorders (CAPD)

\section{Wstęp}

Centralne zaburzenia przetwarzania słuchowego (Central Auditory Processing Disorders - CAPD) są definiowane przez American Speech-Language-Hearing Association (ASHA) jako deficyty w przetwarzaniu informacji słuchowej na poziomie centralnego układu nerwowego. Rozpoznaje się je, gdy nieprawidłowa jest co najmniej jedna $\mathrm{z}$ wyższych funkcji słuchowych: lokalizacja źródła dźwięków, dyskryminacja dźwięków, identyfikacja wzorców dźwiękowych, czasowy aspekt słyszenia, rozumienie mowy w obecności dystraktorów [ASHA, 2005]. Dzieci $\mathrm{z}$ deficytem $\mathrm{w}$ procesach przetwarzania informacji słuchowej w swoim zachowaniu charakteryzują się: a) brakiem stałości odpowiedzi na bodziec słuchowy na to samo polecenie potrafią zareagować prawidłowo, a następnym razem zupełnie go nie zrozumieć; b) krótkim czasem skupienia uwagi słuchowej - łatwo się rozpraszają; c) nadmiarowymi, często natychmiastowymi, reakcjami na różne bodźce słuchowe, pozostające bez znaczenia dla prowadzonej aktywności; d) nadwrażliwością słuchową budzącą często nieadekwatne uczucie niepokoju lub lęku; d) trudnościami w rozumieniu złożonych poleceń, nawet tych, których zasób słownikowy jest zautomatyzowany; e) trudnościami w zapamiętaniu informacji podanej na drodze słuchowej oraz z utrzymaniem jej w pamięci trwałej, co wiąże się z koniecznością powtarzania poleceń i instrukcji słownych [Jerger, Musiek, 2000; Keith, 2004].

Wymienione cechy CAPD niewątpliwie przyczyniają się do zaburzeń w prawidłowym funkcjonowaniu poznawczym dziecka. Efektem mogą być trudności szkolne dziecka narastające wraz ze wzrostem wymagań edukacyjnych. Patrząc na zaburzenia dzieci z z perspektywy teoriopoznawczej, przyjmuje się, że właściwości funkcjonowania poznawczego, w tym - jak można sądzić - związane z obecnością CAPD, są ściśle powiązane $\mathrm{z}$ funkcjonowaniem dzieci w sferze emocjonalnej i społecznej [Derryberry, Reed, 2002; za: Święcicka, 2011]. Obecnie proponowane modele terapii CAPD koncentrują się na treningu poznawczym zaburzonych funkcji, nauce kompensowania deficytów, sposobach wprowadzania zmian w otoczeniu oraz technikach postępowania wobec pacjenta [Bamiou, 2001; Gillam i wsp., 2008; Pokorni i wsp., 2006; Senderski, 2007; Valentine i wsp., 2006].

Większość autorów sygnalizuje jedynie możliwość wystąpienia w tej grupie dzieci trudności związanych z emocjami lub funkcjonowaniem społecznym w środowisku rówieśniczym. Nieliczni poświęcają zagadnieniu „więcej niż hasło”, określając dzieci z CAPD jako „nieśmiałe”, „o niskim poczuciu własnej wartości”, „pozostające na uboczu” [Keith, 2004], a także „sfrustrowane” i „wycofane” lub charakteryzujące się „zaburzoną komunikacją interpersonalną" [Bellis, 2002]. Autorzy prac nie podają źródeł doniesień naukowych, więc pozostają one jedynie obserwacjami wymagającymi dalszych empirycznych weryfikacji.
Do przeprowadzenia badania w grupie dzieci z CAPD zaproponowano Kwestionariusz Mocnych Stron i Trudności (SDQ) Roberta Goodmana z 1997 roku. Jest to skala objawów psychopatologii stosowana w badaniach przesiewowych, naukowych i klinicznych, służąca do oceny trudności emocjonalnych i społecznych oraz problemów przejawianych w zachowaniu dzieci i młodzieży. W Polsce kwestionariusz SDQ zastosowano w wersji somoopisowej wobec młodzieży z populacji ogólnej - ustalając normy dla polskiej populacji [Mazur, Tabak, Kołoło, 2007] oraz jako jeden z baterii testów do oceny jakości życia związanej ze zdrowiem [Mazur i wsp., 2008]. Kwestionariusz SDQ w wersji dla rodziców wykorzystano do badań polskich dzieci głuchych i słabosłyszących [Kobosko, 2012], a wyniki porównano z otrzymanymi w innych krajach europejskich [np. Hintermair, 2007; Meistad, Heiling, Svedin, 2009]. Skalą tą posłużono się także w grupie pacjentów z obniżonymi możliwościami intelektualnymi [Muris, Mass, 2004] oraz zastosowano ją w badaniach longitudinalnych do oszacowania i monitorowania zmian w obszarze zdrowia psychicznego dzieci i młodzieży [Ford i wsp., 2007]. Za zastosowaniem kwestionariusza SDQ w grupie dzieci z CAPD dodatkowo przemawia wynik wskazujący na istnienie korelacji pomiędzy stopniem opanowania kompetencji językowych i komunikacyjnych a zaburzeniami $\mathrm{w}$ sferze emocjonalnej i behawioralnej stwierdzony u dzieci o różnym stopniu ubytku słuchu [Fellinger, Holzinger, Pollard, 2012] i z upośledzeniem umysłowym [Muris, Mass, 2004].

\section{Cel pracy}

Celem badań była ocena zdrowia psychicznego dzieci z CAPD - rozumianego jako trudności emocjonalne, społeczne oraz problemy przejawiające się w zachowaniu - z zastosowaniem Kwestionariusza Mocnych Stron i Trudności (SDQ) w ocenie rodziców w porównaniu $\mathrm{z}$ rezultatami pochodzącymi z badania grupy dzieci o prawidłowym rozwoju i w podobnym wieku z populacji ogólnej. Postawiono pytania badawcze dotyczące istnienia różnic w nasileniu problemów emocjonalno-społecznych między dziećmi z CAPD a dziećmi słyszącymi o prawidłowym rozwoju w ocenie rodziców, jak i tego, jakich obszarów różnice te dotyczą. Jako kolejne postawiono pytanie o związek między trudnościami emocjonalno-społecznymi a trudnościami szkolnymi dzieci z CAPD w opinii rodziców. Uwzględniono także czynniki socjodemograficzne, takie jak płeć i wiek dziecka, wiek rodzica oraz liczba rodzeństwa. Ponadto poszukiwano odpowiedzi na pytanie, czy zmienne takie jak: wiek dziecka, wiek rodzica, trudności szkolne dziec$\mathrm{ka}$ (w ocenie rodzica) oraz zadowolenie rodzica $\mathrm{z}$ terapii mogą być predyktorami problemów w sferze zdrowia psychicznego (ogółem) doświadczanych przez dzieci z CAPD.

\section{Metody badań}

\section{Osoby badane}

Badaniami objęto 149 rodziców: 74 rodziców dzieci ze zdiagnozowanymi centralnymi zaburzeniami przetwarzania 
Tabela 1. Wartości współczynników rzetelności alfa Cronbacha dla Kwestionariusza Mocnych Stron i Trudności (SDQ) w wersji dla rodziców otrzymane w badaniach dzieci z CAPD i dzieci zdrowych

\begin{tabular}{ccc}
\hline $\begin{array}{c}\text { Kwestionariusz SDQ } \\
\text { (wersja dla rodziców) }\end{array}$ & $\begin{array}{c}\text { Wartości alfa Cronbacha } \\
\text { Dzieci z CAPD }\end{array}$ & $\begin{array}{c}\text { Wartości alfa Cronbacha } \\
\text { Dzieci zdrowe }\end{array}$ \\
\hline Skala Nadaktywności (H) & 0,761 & 0,817 \\
\hline Skala Symptomy Emocjonalne (ES) & 0,662 & 0,593 \\
\hline Skala Trudności w Zachowaniu (CP) & 0,508 & 0,599 \\
\hline Skala Problemy z Rówieśnikami (PP) & 0,697 & 0,564 \\
\hline Skala Zachowań Prospołecznych (PBS) & 0,712 & 0,686 \\
\hline Wynik Ogólny (TDS) H + ES +CP + PP & 0,777 & 0,826 \\
\hline
\end{tabular}

słuchowego (CAPD), w tym 60 matek i 14 ojców, oraz 75 rodziców dzieci słyszących z populacji ogólnej, w tym 68 matek i 7 ojców. W obu grupach było istotnie więcej matek niż ojców biorących udział w ocenie sfery zdrowia psychicznego dziecka. W grupie dzieci z CAPD było 26 dziewczynek i 48 chłopców, a w grupie kontrolnej 42 dziewczynki i 33 chłopców. Wiek dzieci znajdował się w przedziale od 7 do 14 lat. Diagnoza medyczna obejmowała konsultację lekarza audiologa i foniatry, w tym badanie audiometrii tonalnej, impedancyjnej oraz badanie wyższych funkcji słuchowych: P300 (potencjał poznawczy), TSD (Test Sekwencji Długości), TRC (Test Rozdzielnouszny Cyfrowy), TRS (Test Rozdzielnousznego Słyszenia). Rodzice wypełnili Kwestionariusz SDQ oraz Ankietę informacyjną.

\section{Narzędzia badawcze}

Ankieta informacyjna zawiera pytania dotyczące danych demograficznych rodziców i dzieci, problemów zdrowotnych dzieci, zadowolenia rodziców z terapii dzieci oraz trudności szkolnych dzieci. Odpowiedź mówiącą o nasileniu trudności szkolnych i zadowoleniu z terapii dziecka rodzic zaznaczał na skali od 0 do 10 .

Kwestionariusz Mocnych Stron i Trudności (Strengths and Difficulties Questionnaire - SDQ) R. Goodmana jest narzędziem stosowanym do oceny nasilenia symptomów trudności emocjonalnych, społecznych i problemów w zachowaniu dzieci już od 3 roku życia, a górną granicę stanowi 16 rok życia dziecka. Składa się z 25 stwierdzeń opisujących różne cechy badanego, z czego 10 stwierdzeń dotyczy mocnych stron dziecka, 14 opisuje jego słabe strony, 1 jest stwierdzeniem neutralnym. Kwestionariusz SDQ zbudowany jest z 5 podskal (po 5 stwierdzeń każda): Nadaktywność/ Problemy w Koncentracji Uwagi (Hiperactivity/Innatention - HA), np. niespokojny, nadmiernie ożywiony, nie może wytrzymać dłużej $w$ jednym miejscu; Symptomy Emocjonalne (Emotional Symptoms - ES), np. często czuje się nieszczęśliwy, przygnębiony lub płaczliwy; Problemy w Zachowaniu (Conduct Problems CP), np. często bije się z innymi dziećmi lub je terroryzuje; Problemy z Rówieśnikami (Peer Problems - PP), np. jest raczej samotny, ma skłonność do bawienia się samemu; $\mathrm{Za}-$ chowania Prospołeczne (Prosocial Behavior Symptoms PBS), np. często zgłasza się do pomocy innym. Pierwsze 4 podskale wchodzą w skład Wyniku Ogólnego (Total Difficulties Score - TDS) mówiącego o nasileniu symptomów psychopatologii ogółem. Kwestionariusz SDQ może być wypełniany przez rodziców i nauczycieli oraz przez same dzieci, jeśli ukończyły 11 rok życia. Osoba wypełniająca Kwestionariusz SDQ ma za zadanie określić, czy w czasie ostatniego pół roku podane stwierdzenia odnoszące się do funkcjonowania dziecka w sferze zdrowia psychicznego są „całkowicie nieprawdziwe”, „częściowo prawdziwe”, „całkowicie prawdziwe”. Odpowiedzi punktowane są od 0 do 2 punktów w odniesieniu do stwierdzeń negatywnych i od 2 do 0 punktów względem stwierdzeń pozytywnych. Wynik ogólny Kwestionariusza SDQ mieści się w zakresie od 0 do 40 punktów. Wysoka liczba punktów wiąże się ze wzrostem nasilenia trudności badanego dziecka. Wyniki dla poszczególnych podskal oraz wynik ogólny skategoryzowane są jako: „w normie” (normal), „na granicy normy” (borderline), „wynik nieprawidłowy" (abnormal).

Niestety, stosując Kwestionariusz SDQ w grupie dzieci z CAPD, nie możemy odnieść się do norm polskich, stąd potrzeba wyłonienia grupy kontrolnej. W Polsce dostępne są tylko normy dla wersji samoopisowej kwestionariusza SDQ dla młodzieży [Mazur, Tabak, Kołoło, 2007], a badacze najczęściej odwołują się do norm angielskich kwestionariusza SDQ [Becker i wsp., 2004]. W krajach, w których korzystano z opisywanego narzędzia, obserwuje się podobne wyniki, jeśli chodzi o normy, ale są też różnice [Meistad, Heiling, Svedin, 2009], dlatego optymalne byłoby opracowywanie norm dla każdego kraju.

Kwestionariusz Mocnych Stron i Trudności wypełniany przez rodzica (opiekuna) dziecka cechuje duża moc dyskryminacyjna w obszarze różnicowania dzieci należących do populacji ogólnej i klinicznej [Becker i wsp., 2004]. Za jego zastosowaniem przemawia włączenie itemów opisujących nie tylko negatywne, lecz także pozytywne strony dziecka, przystępna forma oraz szeroki zasięg międzynarodowy [Becker i wsp., 2004; Mazur, Tabak, Kołoło, 2007]. W przeprowadzonych badaniach współczynniki zgodności wewnętrznej a Cronbacha dla kwestionariusza SDQ przyjmują wartość od 0,78 do 0,51 , gdy wypełniającymi byli rodzice dzieci z CAPD. Natomiast gdy kwestionariusz ten wypełniali rodzice dzieci o prawidłowym rozwoju, współczynnik ten przybierał wartości od 0,83 do 0,56 (Tabela 1). Do analizy statystycznej wykorzystano test T-Studenta i test U Manna-Whitneya do porównań średnich międzygrupowych oraz analizę regresji liniowej wstecznej. 


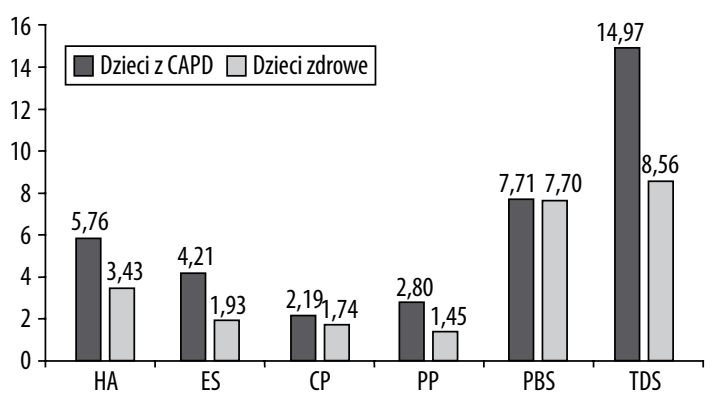

Rycina 1. Wyniki Kwestionariusza Mocnych Stron i Trudności (SDQ) (średnie) dla wyniku ogólnego (TDS) i podskal (HA - Nadaktywność, ES - Symptomy Emocjonalne, CP - Problemy w Zachowaniu, PP - Problemy z Rówieśnikami, PBS - Zachowania Prospołeczne) uzyskane przez dzieci z CAPD i dzieci zdrowe w ocenie rodziców

\section{Wyniki}

Zdrowie psychiczne dzieci z CAPD oraz dzieci o prawidłowym rozwoju w ocenie rodziców

Dzieci z CAPD w ocenie rodziców przejawiają większe nasilenie problemów emocjonalno-społecznych i behawioralnych niż dzieci o prawidłowym rozwoju (wynik ogólny TDS - test T-Studenta $-\mathrm{t}(150)=6,92 ; \mathrm{p}=0,000)$. Dzieci z CAPD charakteryzuje istotnie większe nasilenie symptomów nadaktywności i problemów w koncentracji uwagi (skala HA - test T-Studenta - $\mathrm{t}(150)=5,99 ; \mathrm{p}=0,000)$. Grupę dzieci z CAPD charakteryzuje istotnie większe nasilenie symptomów emocjonalnych (skala ES - test T-Studenta $-\mathrm{t}(150)=6,65 ; \mathrm{p}=0,000)$, a także trudności $\mathrm{w}$ kontaktach $\mathrm{z}$ rówieśnikami (skala $\mathrm{PP}$ - test T-Studenta $-\mathrm{t}(150)=4,2$; $\mathrm{p}=0,000)$ (Rycina 1, Tabele 2 i 3).

Wyniki surowe kwestionariusza SDQ (wynik ogólny TDS) dla grupy dzieci z CAPD oraz dzieci słyszących o prawidłowym rozwoju zostały przeliczone na skalę stenową [Brzeziński, 2000], co między innymi z powodu dość małej liczebności grup należy traktować z dużą ostrożnością. Wyniki przeliczone na steny pozwalają na umiejscowienie wyniku ogólnego SDQ danego dziecka uzyskanego w ocenie rodziców względem wyników innych dzieci $\mathrm{z}$ danej populacji (Tabela 4).

Zdrowie psychiczne dzieci z CAPD oraz dzieci o prawidłowym rozwoju w ocenie rodziców a płeć dziecka

Płeć dziecka z CAPD, jak i płeć dziecka o prawidłowym rozwoju, nie różni w sposób istotny problemów obserwowanych przez rodziców. W percepcji rodziców dziewczęta i chłopcy doświadczają problemów emocjonalno-społecznych i behawioralnych w podobnym nasileniu (Rycina 2).

Zdrowie psychiczne dzieci z CAPD w ocenie rodziców a wiek dziecka

Stwierdzono, że istnieje słaba pozytywna korelacja ( $\mathrm{r}$ Pearsona $-r=0,25 ; p<0,05$ ) między nasileniem symptomów emocjonalnych a wiekiem dziecka. Im dziecko z CAPD starsze, tym większe, w ocenie rodziców, przejawia trudności emocjonalne. W odniesieniu do pozostałych sfer zdrowia psychicznego mierzonych kwestionariuszem SDQ nie stwierdzono związku wieku dziecka z CAPD z nasileniem przejawianych trudności.

\section{Zdrowie psychiczne dziecka z CAPD a liczba rodzeństwa}

Okazało się, że dzieci z CAPD posiadające rodzeństwo charakteryzują się w ocenie rodziców mniejszym nasileniem problemów w sferze nadaktywności i koncentracji uwagi (skala HA - test T-Studenta $-\mathrm{t}(72)=2,09 ; \mathrm{p}<0,05$ ) oraz $\mathrm{w}$ kontaktach $\mathrm{z}$ rówieśnikami (skala $\mathrm{PP}$ - test T-Studenta $-\mathrm{t}(72)=2,44 ; \mathrm{p}<0,05)$.

Zdrowie psychiczne dziecka z CAPD a problemy szkolne

Na istnienie problemów szkolnych w badanej grupie dzieci z CAPD wskazało 57 rodziców. Okazało się, że dzieciom

Tabela 2. Rozkład wyników Kwestionariusza Mocnych Stron i Trudności (SDQ) uzyskanych przez dzieci z CAPD i dzieci zdrowe w ocenie rodziców w kategoriach: norma, borderline, wynik nieprawidłowy (wg norm angielskich)

\begin{tabular}{|c|c|c|c|c|c|c|}
\hline \multirow{3}{*}{$\begin{array}{c}\text { Skale SDQ } \\
\text { HA - Nadaktywność }\end{array}$} & \multicolumn{3}{|c|}{ Dzieci z CAPD } & \multicolumn{3}{|c|}{ Dzieci zdrowe } \\
\hline & \multirow{2}{*}{$\begin{array}{c}\begin{array}{c}\text { Norma } \\
\text { n (\%) }\end{array} \\
37(47,4 \%)\end{array}$} & \multirow{2}{*}{$\begin{array}{c}\begin{array}{c}\text { Borderline } \\
\text { n (\%) }\end{array} \\
14(17,9 \%)\end{array}$} & \multirow{2}{*}{$\begin{array}{c}\begin{array}{c}\text { Wynik } \\
\text { nieprawidłowy } \\
\text { n (\%) }\end{array} \\
27(34,6 \%)\end{array}$} & \multirow{2}{*}{$\begin{array}{c}\begin{array}{c}\text { Norma } \\
\text { n (\%) }\end{array} \\
59(79,7 \%)\end{array}$} & $\begin{array}{l}\text { Borderline } \\
\text { n (\%) }\end{array}$ & $\begin{array}{c}\text { Wynik } \\
\text { nieprawidtowy } \\
\text { n (\%) }\end{array}$ \\
\hline & & & & & $(9,5 \%)$ & $8(10,8 \%)$ \\
\hline $\begin{array}{l}\text { ES - Symptomy } \\
\text { Emocjonalne }\end{array}$ & $36(46,2 \%)$ & $6 \quad(7,7 \%)$ & $36(46,2 \%)$ & $58(78,4 \%)$ & $10(13,5 \%)$ & $6 \quad(8,1 \%)$ \\
\hline $\begin{array}{l}\text { CP - Problemy } \\
\text { w Zachowaniu }\end{array}$ & 44 (58,4\%) & $18(23,1 \%)$ & $16(20,5 \%)$ & $53(71,6 \%)$ & $11(14,9 \%)$ & $10(13,5 \%)$ \\
\hline $\begin{array}{l}\text { PP - Problemy } \\
\text { z Rówieśnikami }\end{array}$ & $40(51,3 \%)$ & $10(12,8 \%)$ & $28(35,9 \%)$ & $55(74,3 \%)$ & $12(16,2 \%)$ & $7 \quad(9,5 \%)$ \\
\hline $\begin{array}{l}\text { PBS - Zachowania } \\
\text { Prospołeczne }\end{array}$ & $64(82,1 \%)$ & $9(11,5 \%)$ & $5 \quad(6,4 \%)$ & $63(85,1 \%)$ & $(8,1 \%)$ & $5 \quad(6,8 \%)$ \\
\hline Wynik Ogólny TDS & $29(37,2 \%)$ & 22 (28,2\%) & $27(34,6 \%)$ & $62(83,8 \%)$ & $(4,1 \%)$ & $9(12,2 \%)$ \\
\hline
\end{tabular}


Tabela 3. Problemy emocjonalne i trudności w zachowaniu dzieci z CAPD i dzieci zdrowych (dziewczynek i chłopców) uzyskane w Kwestionariuszu Mocnych Stron i Trudności (SDQ) w ocenie rodziców (M - średnia, SD - odchylenie standardowe)

\begin{tabular}{|c|c|c|c|c|c|c|}
\hline \multirow{2}{*}{ Skale SDQ } & \multicolumn{3}{|c|}{ Dzieci z CAPD } & \multicolumn{3}{|c|}{ Dzieci zdrowe } \\
\hline & $\begin{array}{l}\text { Chtopcy } \\
\text { M (SD) }\end{array}$ & $\begin{array}{c}\text { Dziewczynki } \\
\text { M (SD) }\end{array}$ & $\begin{array}{l}\text { Razem } \\
\text { M (SD) }\end{array}$ & $\begin{array}{l}\text { Chtopcy } \\
\text { M (SD) }\end{array}$ & $\begin{array}{c}\text { Dziewczynki } \\
\text { M (SD) }\end{array}$ & $\begin{array}{l}\text { Razem } \\
\text { M (SD) }\end{array}$ \\
\hline HA - Nadaktywność & $5,7(2,17)$ & $5,61(2,54)$ & $5,75(2,27)$ & $3,87(2,45)$ & $3,09(2,51)$ & $3,43(2,5)$ \\
\hline ES - Symptomy Emocjonalne & $4,29(2,36)$ & $4,3(2,47)$ & $4,21(2,39)$ & $1,96(1,85)$ & $1,95(1,72)$ & $1,93(1,77)$ \\
\hline CP - Problemy w Zachowaniu & $2,8(1,6)$ & $2,38(1,52)$ & $2,19(1,57)$ & $1,65(1,55)$ & $1,8(1,71)$ & $1,74(1,63)$ \\
\hline PP - Problemy z Rówieśnikami & $3,06(2,54)$ & $2,23(1,96)$ & $2,8(2,31)$ & $1,75(1,77)$ & $1,23(1,24)$ & $1,45(1,5)$ \\
\hline PBS - Zachowania Prospołeczne & $7,52(2,06)$ & $8,38(1,55)$ & $7,71(1,9)$ & $7,43(1,84)$ & $7,9(1,84)$ & $7,7(1,8)$ \\
\hline Wynik Ogólny TDS & $15,2(5,93)$ & $14,53(5,74)$ & $14,97(5,81)$ & $9,18(6,08)$ & $8,09(5,19)$ & $8,56(5,58)$ \\
\hline
\end{tabular}

Tabela 4. Normy stenowe dla wyniku ogólnego Kwestionariusza SDQ w wersji dla rodziców dzieci z CAPD i rodziców dzieci o prawidłowym rozwoju

\begin{tabular}{cccccccccc}
\hline \multicolumn{10}{c}{ Steny } \\
\hline $\mathbf{1}$ & $\mathbf{2}$ & $\mathbf{3}$ & $\mathbf{4}$ & $\mathbf{5}$ & $\mathbf{6}$ & $\mathbf{7}$ & $\mathbf{8}$ & $\mathbf{9}$ & $\mathbf{1 0}$ \\
\hline $0-4$ & 5 & $6-7$ & $8-12$ & $13-14$ & $15-17$ & $18-20$ & $21-23$ & $24-27$ & $28+$ \\
\hline 0 & 1 & SDQ (wynik ogólny) punkty surowe - dzieci o prawidłowym rozwoju & & \\
\hline & 2 & $3-5$ & 6 & $7-9$ & $10-13$ & $14-17$ & $18-20$ & $21+$ \\
\hline
\end{tabular}

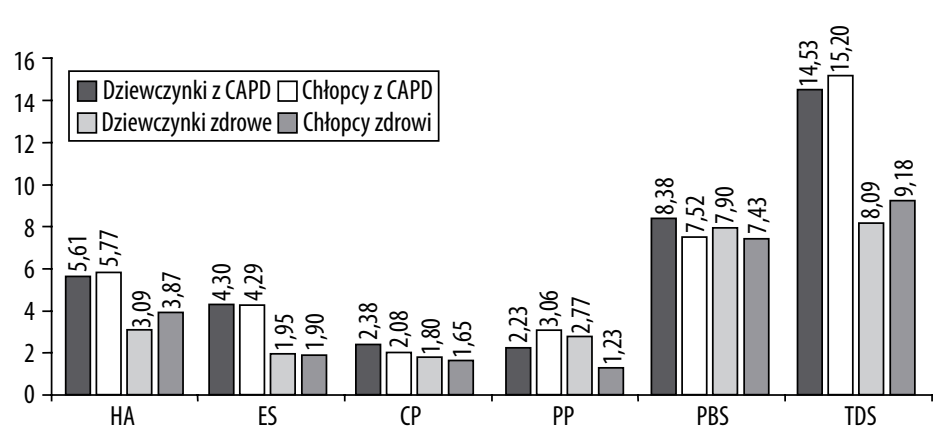

Rycina 2. Wyniki Kwestionariusza Mocnych Stron i Trudności (SDQ) (średnie) uzyskane przez dziewczynki z CAPD i dziewczynki zdrowe oraz chłopców z CAPD i chłopców zdrowych $w$ poszczególnych podskalach (HA - Nadaktywność, ES - Symptomy Emocjonalne, CP - Problemy w Zachowaniu, PP Problemy z Rówieśnikami, PBS Zachowania Prospołeczne) i wynik ogółem (TDS)

z CAPD z problemami szkolnymi towarzyszy istotnie większe nasilenie objawów nadaktywności i deficytów uwagi (skala HA - test T-Studenta $-\mathrm{t}(70)=2,29 ; \mathrm{p}<0,01$ ) oraz większe nasilenie trudności $\mathrm{w}$ kontaktach $\mathrm{z}$ rówieśnikami (skala PP - test T-Studenta $-\mathrm{t}(70)=2,1 ; \mathrm{p}<0,01)$.

Zdrowie psychiczne dziecka z CAPD a wiek i wykształcenie rodzica

Wiek rodzica ma związek z jego postrzeganiem symptomów emocjonalnych u dziecka. W ocenie starszych rodziców dzieci z CAPD mają większe nasilenie problemów w tej sferze (skala ES - $r$ Pearsona - r=0,29; p<0,05). Wykształcenie rodziców nie pozostaje w związku z ocenianym przez nich nasileniem problemów emocjonalno-społecznych i behawioralnych dzieci z CAPD.
Czy zdrowie psychiczne dziecka z CAPD można przewidywać na podstawie wieku dziecka, wieku rodzica, nasilenia problemów szkolnych i zadowolenia rodziców $\mathrm{z}$ terapii?

W celu odpowiedzi na to pytanie przeprowadzono analizę regresji krokowej wstecznej, w której predyktorami problemów emocjonalno-społecznych i behawioralnych (wynik ogólny SDQ i każdej podskali oddzielnie) były następujące zmienne: wiek dziecka, wiek rodzica, nasilenie problemów szkolnych i zadowolenie rodzica $z$ terapii dziecka. Istotne okazały się trzy modele regresji, w których zmienną zależną były trudności emocjonalne, trudności w kontaktach $\mathrm{z}$ rówieśnikami oraz nasilenie problemów emocjonalno-społecznych i behawioralnych ogółem, a predyktorami zmienne wyżej wymienione. W pierwszym 
modelu otrzymano $\mathrm{F}(4,47)=2,91 ; \mathrm{p}<0,05$, a zmienność wyjaśniona wynosi 19,9\% - istotne znaczenie dla przewidywania stopnia trudności emocjonalnych u dziecka z CADP ma wiek rodzica $(\beta=0,272 ; \mathrm{p}<0,05)$ oraz w pewnym stopniu (tendencja statystyczna) nasilenie trudności szkolnych $(\beta=0,259 ; p=0,058)$. Trudności emocjonalne dzieci z CAPD są tym większe, im starszy jest rodzic i im bardziej nasilone są problemy szkolne dziecka. $Z$ kolei, jeśli chodzi o kontakty $\mathrm{z}$ rówieśnikami $(\mathrm{F}(4,47)=2,69 ; \mathrm{p}<0,05$; zmienność wyjaśniona wynosi $18,6 \%)$, istotne dla ich przewidywania u dzieci z CAPD okazało się nasilenie problemów szkolnych $(\beta=0,38 ; p=0,007)$, co oznacza, że im więcej problemów szkolnych ma dziecko, tym więcej doświadcza problemów w relacjach $\mathrm{z}$ rówieśnikami w percepcji rodziców. Istotnym statystycznie predyktorem nasilenia problemów emocjonalno-społecznych i behawioralnych ogółem okazały się jedynie trudności szkolne dzieci z CAPD, a więc im bardziej nasilone są problemy szkolne, tym większych trudności emocjonalno-społecznych i behawioralnych należy oczekiwać u dzieci z CAPD - $(\mathrm{F}(94,47)=2,79 ; \mathrm{p}<0,05$; zmienność wyjaśniona równa się $19,2 \% ; \beta=0,36, p=0,01)$.

\section{Dyskusja wyników}

Dzieci z CAPD, zarówno dziewczynki jak i chłopcy, przejawiają w ocenie rodziców większe nasilenie problemów w sferze emocji, relacji społecznych i zachowania niż ich zdrowi rówieśnicy. Ogólny wynik kwestionariusza SDQ dzieci z CAPD jest średnio znacznie wyższy niż u dzieci zdrowych. Dzieci z grupy badawczej w ocenie rodziców charakteryzuje 3,8 razy większa częstotliwość symptomów psychopatologii niż ma to miejsce w przypadku dzieci o typowym rozwoju. Wyniki o podwyższonym dwukrotnie występowaniu trudności z sferze zdrowia psychicznego uzyskano w odniesieniu do dzieci głuchych i niedosłyszących z wykorzystaniem kwestionariusza SDQ w Polsce [Kobosko, 2012], a także w innych krajach europejskich [np. Fellinger, 2009; Hintermair, 2007].

Wyniki dzieci z CAPD uzyskane w kwestionariuszu SDQ mówiące o ich funkcjonowaniu w sferze zdrowia psychicznego są podobne niezależnie od płci dziecka. Jednakże w badaniach Hintermaira (2007) wykazano, że chłopсу z badanej grupy dzieci głuchych prezentowali więcej symptomów psychopatologii niż dziewczynki. W grupie dzieci z CAPD nie stwierdzono tej zależności, być może $\mathrm{z}$ powodu udziału w badaniu dużej grupy dzieci młodszych. Odnotowano jedynie nieznacznie więcej problemów z rówieśnikami zgłaszanych przez rodziców chłopców niż dziewczynek z CAPD. Okazało się, że wiek dziecka z CAPD pozostaje $\mathrm{w}$ związku z nasileniem problemów emocjonalnych (wynik podskali ES), a więc im dziecko starsze, tym w ocenie rodziców doświadcza więcej trudności w sferze emocji. Otrzymano także rezultat mówiący o tym, że dzieci z CAPD posiadające rodzeństwo charakteryzowały się według rodziców mniejszym nasileniem problemów w sferze nadaktywności i koncentracji uwagi oraz $\mathrm{w}$ kontaktach $\mathrm{z}$ rówieśnikami, co wskazuje na modyfikującą rolę obecności rodzeństwa dzieci z CAPD dla ich funkcjonowania emocjonalno-społecznego. Wiek rodzica dziecka z CAPD ma znaczenie dla postrzegania problemów zdrowia psychicznego dzieci, zwłaszcza w sferze emocjonalnej: rodzice starsi spostrzegają ich więcej u swoich dzieci z CAPD niż ma to miejsce w przypadku rodziców młodszych.

Na problemy szkolne w badanej grupie dzieci z CAPD wskazało w ankiecie informacyjnej około $70 \%$ rodziców. Dzieciom tym towarzyszyło większe nasilenie objawów nadaktywności i deficytów uwagi oraz większe nasilenie trudności w kontaktach $\mathrm{z}$ rówieśnikami niż dzieciom z diagnozą CAPD, lecz bez problemów szkolnych. Nasilenie problemów szkolnych u dzieci z CAPD pozwala na przewidywanie $\mathrm{w}$ tej grupie dzieci problemów w sferze zdrowia psychicznego - im więcej problemów szkolnych doświadcza dziecko z CAPD, tym większego nasilenia problemów emocjonalno-społecznych można spodziewać się $\mathrm{w}$ tej grupie dzieci.

Niestety, w omawianym badaniu nie uwzględniono poziomu kompetencji komunikacyjnej dziecka z CAPD, która bez wątpienia ma związek z zaburzeniami w sferze zdrowia psychicznego. Potwierdzają to wyniki badań Fellingera i współpracowników (2012), w których wykazano, że dzieci głuche osiągające kompetencje językowe i komunikacyjne na poziomie podobnym do kompetencji dzieci z populacji ogólnej miały wskaźniki zaburzeń psychicznych porównywalne $\mathrm{z}$ tymi populacjami.

W Szwecji zastosowano kwestionariusz SDQ w badaniu dzieci głuchych korzystających z implantu ślimakowego w trzech wersjach: dla rodzica, nauczyciela i dziecka (samoopisowy). Rodzice i nauczyciele w podobny sposób oceniali zdrowie psychiczne podopiecznych, natomiast dzieci oceniły swoje trudności emocjonalne i problemy w zachowaniu jako większe [Anmyr i wsp., 2012]. Być może podobne rezultaty uzyskano by w odniesieniu do dzieci z CAPD, co wymaga dalszych badań.

Analiza otrzymanych wyników wskazuje na znacząco zaburzone obszary zdrowia psychicznego dzieci z CAPD, zwłaszcza w sferze emocji i kontaktów społecznych z rówieśnikami. Trudności w kontaktach $\mathrm{z}$ rówieśnikami charakteryzują zarówno dzieci z trudnościami w uczeniu się [Święcicka, 2011], jak i dzieci głuche i niedosłyszące [Fellinger, 2009; Hintermair, 2007; Kobosko, 2012]. Specjalistycznej pomocy wymagają zwłaszcza dzieci z CAPD z trudnościami szkolnymi. Z perspektywy neuropoznawczej dysfunkcje samoregulacji i samokontroli uważa się za mechanizmy zaburzeń przejawiających się w wielu sferach funkcjonowania dziecka, zarówno poznawczej, emocjonalnej, jak i społecznej. Zakres dotychczasowej oferty terapeutycznej kierowanej do dzieci z CAPD, polegającej głównie na stosowaniu treningu słuchowego i treningów umiejętności poznawczych, wymaga zatem rozszerzenia o oddziaływania psychologiczne: trening komunikacji interpersonalnej, socjoterapię, edukację psychologiczną i psychoterapię. Psychoterapia dzieci z CAPD powinna zawsze obejmować pracę terapeutyczną z jego rodziną [Schier, Zalewska, 2006]. Szanse optymalnej zmiany psychologicznego funkcjonowania dzieci z CAPD stwarza podejście poznawczo-relacyjne zaproponowane i realizowane przez Święcicką (2011) jako efektywne w pracy $\mathrm{z}$ dziećmi $\mathrm{z}$ trudnościami w uczeniu się, którym to niejednokrotnie towarzyszą centralne zaburzenia przetwarzania słuchowego. 


\section{Piśmiennictwo:}

1. American Speech-Language-Hearing Association. Central Auditory Processing Disorders - The Role of Audiologist, 2005

2. Anmyr L., Larsson K., Olsson M., Frejid A.: Strengths and difficulties in children with cochlear implants - comparing self-report with reports from parents and teachers. Int J Pediatr Otorhi, 2012; 76(8): 1107-12

3. Bamiou D., Musiek F., Luxon L.M.: Aetiology and clinical presentations of auditory processing disorders - a review. Arch Dis child, 2001; 85(5): 361-65

4. Becker A., Woerner W., Hasselhorn M.: Validation of the parent and teacher SDQ in a clinical sample. Eur Child Adolesc Psychiatry, 2004; 13 (Suppl. 2): 11-16

5. Bellis T.J.: Assessment and Management of Central Auditory Processing Disorders in the Educational Setting - From Science to Practice. Kanada, Delmar Learning, 2002

6. Brzeziński J.: Metodologia badań psychologicznych. Warszawa, Wydawnictwo Naukowe PWN, 2000

7. Fellinger J., Holzinger D., Pollard R.: Mental health of deaf people. Lancet, 2012; 379: 1037-44

8. Fellinger J., Holzinger D, Sattel H. i wsp.: Correlates of mental health disorders among children with hearing impairments. Dev Med Child Neurol, 2009; 51(8): 635-41

9. Ford T., Collishaw S., Meltzer H., Goodman R.: A prospective study of childhood psychopathology: independent predictors of change over three years. Soc Psych Psych Epid, 2007; 42(12): 953-61

10. Gillam R.B., Loeb D.F., Hoffman L.M. i wsp.: The efficacy of Fast ForWord language intervention in school - age children with language impairment. J Speech Lang Hear Res, 2008; 51(1): 97-119

11. Hintermair M.: Prevalence of socioemotional problems in deaf and hard of hearing children in Germany. Am Ann Deaf, 2007; 152(3): 320-30

12. Jerger J., Musiek F.: Report consensus conference on the diagnosis of auditory processing disorders in school-aged children. J Am Acad Audiol, 2000; 11(9): 467-74

13. Keith R.W.: Advances in understanding of auditory processing disorders. Otorynolaryngologia, 2004; 3(1): 7-14
14. Kobosko J.: Problemy zdrowia psychicznego dzieci głuchych i słabosłyszących oraz dzieci słyszących z populacji ogólnej w ocenie rodziców. Nowa Audiofonologia, 2012; 1(1): 56-66

15. Mazur J., Tabak I., Kołoło H.: W kierunku lepszej oceny zdrowia psychicznego dzieci i młodzieży. Polska wersja Kwestionariusza Mocnych Stron i Trudności (SDQ). Doświadczenia dwóch badań populacyjnych. Medycyna Wieku Rozwojowego, 2007; 11(1): 13-24

16. Mazur J., Małkowska-Szkutnik A., Dzielska A., Tabak I.: Polska wersja kwestionariuszy do badania jakości życia związanej ze zdrowiem dzieci i młodzieży (KIDSCREEN). Warszawa, Instytut Matki i Dziecka, 2008

17. Meistad L., Heiling K., Svedin C.G.: Mental health and self-image among deaf hard of hearing children. Am Ann Deaf, 2009; 153(5): 504-15

18. Millward K., Hall R.L., Ferguson M., Moore D.: Training speech-in-noise perception in mainstream school children. Int J Pediatr Otorhi, 2011; 75(11): 1408-17

19. Muris P., Maas A.: Strengths and difficulties as correlates of attachment style in institutionalized and non-institutionalized children with below-average intellectual abilities. Child Psychiat Hum D, 2004; 34: 317-28

20. Pokorni J.L., Worthington C.K., Jamison P.J.: Phonological awareness intervention: comparison of Fast ForWord, Earobics, and LiPS. J Edu Res, 2004; 97(3): 147-57

21. Schier K., Zalewska M.: Krewni i znajomi Edypa. Kliniczne studia dzieci i ich rodziców. Warszawa, SCHOLAR, 2006

22. Senderski A.: Ośrodkowe zaburzenia słuchu u dzieci w wieku szkolnym. Warszawa, IFPS, 2007

23. Święcicka M.: Psychoterapia dzieci z trudnościami w uczeniu się. (W:) Grzesiuk L., Suszek H. (red.). Psychoterapia. Problemy pacjentów. Podręcznik akademicki, t. 5., Warszawa, Eneteia - Wydawnictwo Psychologii i Kultury, 2011

24. Valentine D., Hedrick M.S., Swanson L.A.: Effect of an auditory training program on reading, phoneme awareness and language. Percept Mot Skills, 2006; 103(1): 183-96

25. Veuilet E., Magnan A., Ecalle J. i wsp.: Auditory processing disorder in children with reading disabilities: effect of audiovisual training. Brain, 2007; 130(Pt 11): 2915-28 